\title{
Editorial: Inequalities in Access to Education: Failing to Provide Skills-Building and Empowerment to Girls
}

\author{
George Leeson • Sarah Harper
}

Received: 9 October 2012 / Accepted: 9 October 2012 /Published online: 9 November 2012

(C) Springer Science+Business Media Dordrecht 2012

Seventy years ago in 1942, William Beveridge identified five giants of the mid 20th Century - want, disease, ignorance, squalor and idleness. To mark this seminal work, JPA commissioned five thought pieces identifying the new giants of the 21 st Century - poverty, lack of access to health care, lack of access to education, disabled life expectancy, failing intergenerational reciprocity. The first Giants of the $21^{\text {st }}$ Century: longevity and disability by Harper (2011) argued that the $21^{\text {st }}$ century will likely see a significant increase in disability, and at the same time a shift from it being a life course experience to one associated with old age. In the second, Giants of the $21^{\text {st }}$ Century: health inequalities and social justice, Howse (2012) proposed that equity in the provision of healthcare is now an uncontested goal for modern healthcare systems. Giants of the $21^{\text {st }}$ Century: Global Poverty, Inequalities and Ageing in Sub-Saharan Africa: A Focus for Policy and Scholarship by Aboderin (2012) focused on sub-Saharan Africa, carrying the largest prevalence of poverty of any world region. In the fourth piece, Giants of the $21^{\text {st }}$ Century: population ageing and intergenerational justice. Hoffman (2012) presents the view that intergenerational justice, the mitigation of inequality between the generations, will only be sustained in the future by a dual approach of the mutual distribution of resources and facilitating solidarity between the generations. The final piece turns to consider the giant of the inequality in access to education, and the particular impact this has upon women. This combined collection thus presents five new giants for the $21^{\text {st }}$ century and considers how the Century's major challenge of demographic change will interact with these - want has been replaced by poverty, disease by lack of access to health care, ignorance by lack of access to education, squalor and idleness by disabled life expectancy and failing intergenerational reciprocity. These five giants of the $21^{\text {st }}$ century have all had a central theme of inequality - inequality within countries, inequality between regions, and inequalities between generations. The

G. Leeson $\cdot$ S. Harper $(\bowtie)$

Oxford Institute of Population Ageing, University of Oxford, Oxford, UK

e-mail: sarah.harper@ageing.ox.ac.uk 
$21^{\text {st }}$ Century has the potential to slay these giants. It also has the potential to magnify the greatest modern giant of them all - inequality.

It is now accepted by most societies that education is a fundamental human right - one that all individuals are entitled to, regardless of their personal characteristics or circumstances. Yet it is a right which is beset by inequalities, inequalities between countries and inequalities between the genders. The Millennium Development Goals (MDGs) set the target of universal primary schooling by 2015. Yet there are still over 100 million children who are not in school and some 150 million more who are likely to drop out before they complete primary school. Over 60 nations, the majority in Africa, will be unable to ensure universal primary school education by that date.

There is further inequality between the genders, despite the fact that the MDGs also set the target of eliminating gender disparities in primary and secondary education by 2005 and of achieving gender equality by 2015 . There is thus considerable variation in differential gender access to education at both the primary and secondary level. While there is parity in almost all the countries of Central and Eastern Europe, with Central Asia, North America and Western Europe falling slightly behind, in contrast only three counties in the whole of sub-Saharan Africa and Central and West Asia have achieved this. Indeed half the girls in Africa will not complete a primary education. These inequalities persist because traditionally, in terms of educational opportunities, all societies have privileged males over females. Thus disparities in educational attainment and literacy rates today reflect patterns which have been shaped by the policies and practices of the past (UNESCO 2012).

Worldwide, $90 \%$ of primary school age children are enrolled in primary or secondary education, but only $77 \%$ in sub-Saharan Africa. Sub-Saharan Africa does not only have lower educational attainment than other regions, it is also the region with the greatest gender disparity against women. The highest gender disparity in educational attainment exists in Benin, Burkina Faso, Chad, Malawi and Senegal. In these countries, less than one-half as many women as men have completed any formal education. In 47 countries, girls are less likely than boys to enter the last grade of primary education. The most extreme situations are found in the Central African Republic, Chad, the Democratic Republic of the Congo and Yemen, where girls have around two thirds of the participation rate of boys. The region also has the lowest overall rate of participation in secondary education and the most severe gender disparities. In 2009 , only $32 \%$ of girls had any secondary school education, versus $41 \%$ for boys. Only $27 \%$ of pupils complete upper secondary school programmes, falling as low as $6 \%$ in the Central African Republic, Niger, Somalia and the United Republic of Tanzania.

Yet there is overwhelming evidence that education improves health and well being, and reduces levels of both mortality and fertility (Mlatsheni and Leibbrandt 2009; Palloni et al. 2012). Girls and women not only face the challenges of high fertility and unwanted pregnancies, it is they within the community who are primarily responsible for infant and child health, immunization and nutrition. Indeed there is evidence that a mother's education is the most important determinant of child mortality, more important than household income or wealth, with each additional year of schooling being associated with a 5-10\% reduction in infant mortality (Schultz 1993a) and a 5 to $7 \%$ reduction in child death (Mensch et al. 1985; Schultz 1993b). 
There is also strong association between those countries with a high level of educated women, at least $60-80 \%$ of the female population of reproductive age having completed at least junior secondary education, and those countries with below replacement fertility levels. Similarly those countries with low female education rates of below $40 \%$ of women of childbearing age having completed this level of education also have high TFRs. Girls' secondary education also dramatically affects fertility rates. A World Bank study found that for every 4 years of education that girls attain, fertility rates drop by roughly one birth (Klasen 1999). Other research suggests that doubling the proportion of women with a secondary education reduced average fertility rates from 5.3 to 3.9 children per woman (Herz and Sperling 2004). This is of crucial importance in a finite world, for as the authors point out elsewhere, as if it were possible to bring the TRF of Sub Saharan Africa down to the UN low variant of 1.66 rather than the medium prediction of 2.14 by 2100 , then the world population would reduced by a potential billion people by the end of the century (Harper and Leeson 2012).

This effect of education on fertility is particularly strong in countries that still have relatively high overall fertility levels and hence are in the early phases of their demographic transitions (Skirbekk 2008). Here educating girls gives them skills and access to the labour market, increases the age of first marriage and thus first and number of subsequent births, but also and crucially, it changes the "mind set" of the women and their communities and enables them to recognize the range of alternative choices they can make. Indeed one of the greatest contemporary demographers, Jack Caldwell, identified "ideational change" as the biggest factor in falling fertility (Caldwell 1980), it empowers women to pursue their own preferences in terms of childbearing.

As a recent advocacy report (Rihani 2006) noted girls' secondary education is a tool for poverty alleviation and results in social benefits to the whole society, it equips students with critical thinking enabling civic participation and democratic change. Inequalities in access to education are one of the great giants of the 21 st Century, failing to provide skills-building and empowerment, to those living in the least developed countries, and especially to girls.

\section{References}

Aboderin, I. (2012). Giants of the $21^{\text {st }}$ century: global poverty, inequalities and ageing in Sub-Saharan Africa: a focus for policy and scholarship. Journal of Population Ageing, 5(2), 87-90.

Caldwell, J. C. (1980). Mass education as a determinant of the timing of fertility decline. Population and Development Review, 6(2), 225-255.

Harper, S. (2011). Giants of the $21^{\text {st }}$ century: longevity and disability. Journal of Population Ageing, 4(4), 203-206.

Harper, S. and Leeson, G. (2012). The role of education in reducing maximum world population, OIPA Working Paper.

Herz, B., \& Sperling, G. (2004). What works in girls' education. New York: Council on Foreign Relations. 2004.

Hoffman, J. (2012). Giants of the $21^{\text {st }}$ century: population ageing and intergenerational justice. Journal of Population Ageing, 5(3), 147-150.

Howse, K. (2012). Giants of the $21^{\text {st }}$ century: health inequalities and social justice. Journal of Population Ageing, 5(1), 7-22. 
Klasen, S. (1999). "Does gender inequality reduce growth and development - evidence from cross-country regressions." PRR gender and development working paper series no. 7. Washington: World Bank. Last accessed 14 June 2006. http://www.worldbank.org/gender/prr/wp7.pdf.

Mensch, B., Lentzner, H., \& Preston, S. (1985). Child mortality differential in developing countries. New York: United Nations.

Mlatsheni, C. and Leibbrandt, M. (2009). The Role of Education and Fertility in the Participation and Employment of African Women in South Africa, Development Policy Research unit, University of Cape Town, working paper.

Palloni, A., Novak, B. and Rodrigues de Souza, L. (2012). Female Education, Low Fertility, and Economic Development, Center for Demography and Ecology, University of Wisconsin-Madison., CDE Working Paper No. 2012-03.

Rihani, M. (2006). Keeping the promise. USA: AED.

Schultz, T. P. (1993a). "Investments in the Schooling and Health of Women and Men: Quantities and Returns." Journal of Human Resources, Vol. 28, No. 4, Special Issue: Symposium on Investments in Women's Human Capital and Development, Autumn.

Schultz, T. P. (1993b). Mortality decline in the Low income world. American Economic Review, 83(2), $337-342$.

Skirbekk, V. (2008). Fertility trends by social status. Demographic Research, 18(5), 145-180.

UNESCO. (2012). World atlas of gender inequality in education. Paris: UNESCO Publishing. 